\title{
PENGARUH BUDAYA KUALITAS TERHADAP KINERJA ORGANISASI DENGAN QUALITY FUNCTION DEPLOYMENT SEBAGAI MEDIATOR PADA IKM SEKTOR LOGAM DI JAWA TENGAH
}

\author{
Murni Devi Astuti ${ }^{*}$, Wiwiek R. Adawiyah' ${ }^{1}$, Bambang Setyobudi Iriantoko ${ }^{1}$ \\ ${ }^{1}$ Program Pascasarjana, Magister Manajemen, Universitas Jenderal Soedirman \\ *Email corresponding author: murnideviastuti@yahoo.com
}

\begin{abstract}
Abstrak
Tujuan penelitian ini adalah untuk mengkaji pengaruh positif budaya kualitas terhadap kinerja organisasi yang dimediasi oleh Quality Function Deployment (QFD) pada IKM sektor logam di Jawa Tengah. Unit analisis penelitian adalah IKM sektor logam. Penelitian ini merupakan penelitian kuantitatif dengan teknik pengambilan sempel menggunakan teknik purposive sampling. Responden yang dijadikan sampel dalam penelitian ini dari hasil perhitungan menggunakan rumus slovin sebanyak 93 pemilik IKM logam. Metode analisis yang digunakan untuk menguji hipotesis penelitian adalah regresi linier sederhana, regresi linier dengan pemediasi, dan uji sobel. Hasil penelitian menemukan bahwa budaya kualitas dan QFD berpengaruh positif terhadap kinerja organisasi dimana pengaruh budaya kualitas terhadap kinerja organisasi lebih besar daripada QFD. Pengaruh positif juga ditemukan pada pengaruh budaya kualitas terhadap QFD. Disisi lain, QFD sebagai mediator memberikan efek tidak langsung yang lemah dalam mendukung peningkatan kinerja organisasi melalui budaya kualitas.
\end{abstract}

Kata Kunci: Kinerja Organisasi, Budaya Kualitas, Quality Function Deployment (QFD), Variabel mediasi, IKM Sektor Logam di Jawa Tengah.

\begin{abstract}
The objective of this research is to examine the positive influence of quality culture on organizational performance mediated by Quality Function Deployment (QFD) on SMEs in metal sector in Central Java. The unit of research analysis are SMEs in metal sector. This research is a quantitative study with purposive techniqiue sampling. Respondents used as sample in this research from Slovin calculation are 93 SMEs owner in metal sector. The analytical methods used to test the research hypothesis are simple linear regression, linear regression with mediation, and sobel test. The result of the study finds that quality culture and QFD have positive effect on organizational performance where the influence of quality culture on organizational performance is greater than QFD. A positive effect is also shown by quality culture on QFD. This study also found that the influence of quality culture on organizational performance is greater than QFD. On the other hand, QFD as a mediator has a weak indirect effect in supporting organizational performance improvement through a quality culture.
\end{abstract}

Keywords: Organizational Performance, Quality Culture, Quality Function Deployment, Variabel mediasi, SMEs in Metal Sector in Central Java.

\section{PENDAHULUAN}

Eksistensi IKM atau Industri Kecil dan Menengah secara tidak langsung telah memberikan kontribusi besar pada pembangunan ekonomi di Indonesia. Perkembangan IKM yang semakin meningkat mampu menciptakan banyak unit kerja baru yang tentunya membutuhkan tenaga kerja baru. Kondisi ini berdampak pada terbukanya lapangan pekerjaan dan kesempatan kerja yang lebih besar. Salah satu IKM yang mengalami peningkatan unit dan mampu menyerap banyak 
Pengaruh Budaya Kualitas Terhadap Kinerja Organisasi Dengan Quality Function Deployment sebagai Mediator Pada Ikm Sektor Logam Di Jawa Tengah

tenaga kerja adalah IKM sektor logam di Jawa Tengah. Hal tersebut dapat dilihat pada Tabel 1 berikut ini:

Tabel 1. Data IKM Sektor Logam Di Jawa Tengah Tahun 2015 - Agustus 2018

\begin{tabular}{lcccc}
\hline \multicolumn{1}{c}{ Pengolahan Logam } & $\mathbf{2 0 1 5}$ & $\mathbf{2 0 1 6}$ & $\mathbf{2 0 1 7}$ & $\mathbf{2 0 1 8}$ \\
\hline Jumlah Industri (unit) & 1.104 & 1.137 & 1.196 & 1.226 \\
Jumlah Tenaga Kerja (orang) & 10.866 & 11.267 & 11.362 & 11.392 \\
Jumlah Produksi (kg) & 10.118 .343 & 11.450 .685 & 12.013 .607 & 12.045 .327 \\
\hline
\end{tabular}

Sumber: Dinas Perindustrian dan Perdagangan Jawa Tengah (2018)

Ironisnya, besarnya peranan IKM belum diimbangi dengan kemampuan berdaya saing. Kemampuan daya saing IKM dapat dikatakan masih lemah karena belum bisa menghasilkan produk berkualitas yang mampu memenuhi keinginan dan kebutuhan pelanggan. Banyak pendekatan dapat dilakukan untuk meningkatkan daya saing organisasi. Dalam Manajemen Sumber Daya Manusia (MSDM), peningkatan daya saing organisasi dapat dilakukan dengan mengacu pada praktik - praktik manusia agar dapat memaksimalkan pengaruhnya terhadap kinerja organisasi (Noe, dkk., 2014:5). Hal itu karena kinerja organisasi karena kinerja organisasi merupakan aspek terpenting dari seluruh kegiatan yang dilakukan oleh organisasi.

Salah satu faktor yang dapat mempengaruhi kinerja organisasi adalah budaya kualitas atau quality culture. Budaya kualitas membahas tentang dimensi jaminan kualitas dan dimensi nilai organisasi seperti komitmen, nilai dasar, perilaku, sikap, dan kemampuan anggota organisasi (Ehlers, 2009:346). Disisi lain, menurut Goetsch dan David (2000), budaya kualitas didefinisikan sebagai sebuah sistem nilai yang dihasilkan dari lingkungan yang kondusif untuk memaparkan dan memperbaiki kualitas secara kontinyu, yang terdiri dari nilai - nilai, tradisi, prosedur, dan harapan - harapan untuk mempromosikan kualitas. Dari pendapat tersebut dapat dikatakan bahwa budaya kualitas adalah nilai, komitmen, dan perilaku anggota organisasi untuk selalu mendukung peningkatan kualitas.

Fakta bahwa budaya kualitas menjadi faktor pendukung peningkatan kinerja organisasi dibuktikan dengan hasil penelitian. Pertama, penelitian Wu dkk. (2011) menemukan bahwa budaya kualitas memerankan peranan yang dominan dalam sebuah budaya organisasi terhadap kinerja. Kedua, penelitian pada sektor pendidikan yang dilakukan oleh Ali dan Musah (2012) melalui penelitian survey pada 267 staff akademik Universitas Islam Internasional di Malaysia menunjukan bahwa budaya kualitas berpengaruh kuat terhadap kinerja fakultas Universitas. Ketiga, penelitian Dubey, dkk. (2015) yang dilakukan pada 275 responden dari 760 industri mikro menemukan bahwa budaya kualitas berdampak positif dan memberikan dukungan terhadap peningkatan kinerja organisasi pada SME atau Small Medium Entreprise di India.

Selain budaya kualitas, terdapat faktor lain yang dapat mempengaruhi kinerja organisasi. Faktor tersebut adalah QFD atau Quality Function Deployment. QFD saat ini menjadi salah satu teknik manajemen kualitas yang banyak direkomendasikan oleh industri besar (Besterfield, dkk., 1999). Menurut Akao (1990), QFD merupakan metode untuk mendefinisikan rencana kualitas berdasarkan keinginan - keinginan pelanggan dan kemudian menerjemahkannya menjadi sebuah target rencana dan poin - poin jaminan kualitas yang nantinya digunakan selama proses produksi.

Menciptakan produk sesuai keinginan dan kebutuhan pelanggan membutuhkan biaya produksi yang tinggi dan sumber daya manusia yang besar. Organisasi memerlukan teknik manajemen kualitas yang dapat memenuhi keinginan pelanggan dan meningkatkan proses produksi menjadi lebih efektif dan efisien (Heizer dan Barry, 2015:243). QFD muncul sebagai teknik yang berfokus pada upaya memenuhi keinginan pelanggan. Karena itu, hasil penelitian 
studi kasus Gonzalez, dkk. (2004) menemukan bahwa QFD berhasil membantu organisasi sektor perbankan di Spanyol dalam mempertemukan keinginan - keinginan pelanggan dengan internal prosedur perusahaan demi memenuhi kepuasaan pelanggan. Selain memenuhi kepuasan dan keinginan pelanggan, penerapan QFD juga memberikan keuntungan lain bagi organisasi. Pertama, penelitian Jeong dan Oh (1998) menemukan bahwa penerapan QFD pada industri yang memiliki sumber daya terbatas dapat memaksimalkan keluaran perusahaan yang dihasilkan. Kedua, penelitian Politis (2005) yang dilakukan di sembilan organisasi berbeda di Dubai menemukan bahwa penerapan QFD berhubungan positif dan signifikan dengan kinerja organisasi.

QFD dalam penelitian ini berperan sebagai variabel mediasi. QFD sebagai variabel mediasi muncul sebagai akibat perbedaan hasil pada penelitian sebelumnya. Adanya perbedaan hasil hasil penelitian mengakibatkan adanya bias pengaruh dari budaya kualitas terhadap kinerja organisasi. Pertama, penelitian Munizu, dkk. (2011) pada 167 perusahaan manufaktur berskala menengah dan besar di Kota Makassar menemukan bahwa budaya kualitas mempunyai pengaruh yang sangat lemah dalam mendukung peningkatan kinerja perusahaan. Kedua, penelitian Mosadeghrad (2015) menemukan bahwa budaya kualitas memiliki dampak yang lemah terhadap kinerja organisasi melalui penerapan TQM pada pusat kesehatan di Iran.

Singkatnya, tujuan penelitian ini adalah untuk menambah kajian mengenai manajemen kualitas pada industri kecil. Penelitian TQM secara luas hanya dilakukan pada industri besar dan sering kali mengabaikan penerapannya di industri kecil (Saleheldin, 2009). Akibatnya, penelitian TQM pada industri kecil seperti IKM masih sangat terbatas dan belum terkaji secara jelas. Selain itu, melihat dampak pengembangan budaya kualitas terhadap kinerja organisasi pada industry kecil, adanya perbedaan hasil penelitian yang mengkaji budaya kualitas terhadap kinerja organisasi, dan banyaknya keuntungan dari implementasi QFD bagi organisasi, maka penelitian ini diharapkan juga dapat membantu memberikan kontribusi positif terhadap peningkatan kinerja organisasi dalam hal ini adalah IKM.

\section{TINJAUAN PUSTAKA}

\section{Budaya Organisasi}

Budaya organisasi atau organizational culture dianggap sebagai faktor krusial yang dapat mempengaruhi kinerja organisasi. Menurut Murphy, dkk. (2013), budaya organisasi dipandang cukup luas sebagai salah satu faktor penting dalam kinerja organisasi. Hal itu dibuktikan oleh beberapa hasil penelitian. Pertama, sebuah penelitian yang dilakukan di Timur Tengah berhasil menunjukan bahwa budaya organisasi memiliki hubungan yang erat dengan kinerja organisasi seperti pertumbuhan penjualan, peningkatan pangsa pasar, keuntungan, kualitas, pengembangan produk dan jasa baru, dan kepuasan karyawan (Waal dan Suhail, 2012). Kedua, berdasarkan survey yang dilakukan oleh Chen pada 84 organisasi juga telah menunjukan bahwa budaya organisasi memberikan pengaruh terhadap kinerja organisasi (Indayati dkk, 2012). Ketiga, Ogbonna dan Harris (2000) menemukan adanya hubungan positif signifikan antara budaya organisasi dengan kinerja organisasi. Keempat, penelitian yang dilakukan oleh Tseng (2009) pada perusahaan - perusahaan yang bergerak pada bidang manufaktur, non-manufaktur, perbankan, keuangan dan pemerintahan, di Taiwan menemukan bahwa budaya organisasi berpengaruh secara signifikan terhadap kinerja organisasi. Kelima, penelitian Bashayreh (2014) yang dilakukan pada 18 perusahaan asuransi di Yordania menemukan bahwa budaya organisasi memiliki peranan yang penting pada perusahaan dan secara jelas memberikan dampak positif terhadap kinerja organisasi. Keenam, penelitian Nazarian, dkk. (2017) menemukan bahwa budaya organisasi menjadi salah satu faktor yang mempengaruhi kinerja organisasi karena memiliki hubungan yang signifikan dengan kinerja organisasi pada 96 hotel di London. 
Pengaruh Budaya Kualitas Terhadap Kinerja Organisasi Dengan Quality Function Deployment sebagai Mediator Pada Ikm Sektor Logam Di Jawa Tengah

\section{Budaya Kualitas}

Dalam perkembangannya, budaya kualitas atau quality culture muncul dengan beragam definisi. Menurut Quality Maturity Model (QMM), budaya kualitas dideskripsikan dengan melakukan segalanya dengan benar, melakukan hal yang benar, pembelajaran, sesuai dengan lingkungan bisnis, dan secara eksplisit dan tepat bertujuan untuk meningkatkan kualitas (Wilson, 2015). Sommerville dan Sulaiman (1997) menyebutkan bahwa budaya kualitas adalah menentukan secara jelas nilai dan kepercayaan seperti apa yang dapat mendorong perilaku kualitas para anggotanya dan hal - hal penting apa saja yang perlu ditekankan dalam membangun sebuah budaya kualitas seperti mengubah persepsi dan perilaku sebelum mengupayakan perbaikan kualitas. Hardjoesoedarmo (2004:92) menambahkan bahwa budaya kualitas adalah pola nilai - nilai, keyakinan - keyakinan, dan harapan - harapan yang tertanam dan berkembang di benak anggota organisasi mengenai pekerjaannya dalam menghasilkan produk atau jasa yang berkualitas.

Penciptaan budaya kualitas pada organisasi melibatkan banyak faktor dan sudut pandang yang berbeda. Roldan, dkk. (2012) mengembangkan sebuah pola budaya kualitas dari tiga sudut pandang berbeda tentang kualitas, yaitu error culture (EC), anticipation culture (AC) and creative culture (CC). Adebanjo dan Kehoe (1999) menemukan tujuh faktor yang mempengaruhi budaya kualitas seperti kepemimpinan manajemen senior, keterlibatan dan pemberdayaan karyawan, fokus pada pelanggan, hubungan dengan pemasok, kerjasama tim, pengaruh dengan CEO (Chief Executive Officer), dan budaya organisasi terbuka. Johnson (2000) mengemukakan bahwa terdapat sembilan faktor yang mempengaruhi budaya kualitas yaitu dukungan manajemen puncak terhadap kualitas, rencana strategi terhadap kualitas, fokus pada pelanggan, pelatihan kualitas, pemberdayaan dan keterlibatan karyawan, perbaikan kualitas timkerja, analisis, pengukuran, dan jaminan kualitas. Kanji dan Wallace (2000) mengatakan bahwa budaya kualitas yang dapat menciptakan sebuah keunggulan bisnis memiliki ciri - ciri yang meliputi fokus pada pelanggan, perbaikan terus - menerus, manajemen sumber daya manusia, dan kepemimpinan. Mosadeghrad (2015) mengemukakan bahwa budaya kualitas merupakan salah satu kontruksi TQM sebagai pengembangan budaya organisasi yang berkomitmen untuk lebih menekankan pada kepercayaan, pemberdayaan karyawan, kewirausahaan, timkerja, kerjasama, pengambilan resiko, dan perbaikan terus menerus. Selanjutnya, Dubey, dkk. (2015) menyebutkan bahwa budaya kualitas juga dapat dibangun melalui komunikasi yang efektif.

Tujuan organisasi untuk mengembangkan budaya kualitas adalah untuk mempengaruhi kinerja organisasi secara keseluruhan. Hal tersebut dibuktikan oleh beberapa hasil penelitian yang menemukan bahwa budaya kualitas yang dikembangkan pada lingkungan organisasi mampu memberikan pengaruh signifikan terhadap kinerja organisasi. Pertama, penelitian $\mathrm{Wu}$ dkk. (2011) yang menemukan bahwa budaya kualitas memerankan peranan yang dominan dalam sebuah budaya organisasi terhadap kinerja. Kedua, penelitian survey pada sektor pendidikan yang dilakukan Ali dan Musah (2012) pada 267 staff akademik Universitas Islam Internasional di Malaysia juga menunjukan bahwa budaya kualitas berpengaruh kuat terhadap kinerja fakultas. Ketiga, hasil penelitian yang selaras juga ditemukan oleh Dubey, dkk. (2015) yang menemukan bahwa sebanyak 275 responden dari 760 perusahaan, budaya kualitas memberikan dampak positif dan mendukung peningkatan kinerja SME atau Small Medium Entreprise di India.

\section{QFD}

Salah satu teknik dalam manajemen kualitas yang banyak disarankan menurut Besterfield, dkk. (1999) adalah Quality Function Deployment (QFD). QFD pertama kali diterapkan di Mitsubisi Ltd. di Jepang oleh Yoji Akao dan Mizuno (Politis, 2005). QFD adalah salah satu teknik TQM yang 
digunakan untuk menerjemahkan suara - suara pelanggan menjadi proses produksi dan produk yang sesuai dengan keinginan pelanggan. Menurut Akao (1990), QFD merupakan metode untuk mengembangkan sebuah rencana kualitas dengan tujuan untuk memuaskan pelanggan melalui proses penerjemahan keinginan pelanggan yang kemudian diolah kedalam rencana target dan poin - poin jaminan kualitas yang nantinya digunakan selama proses.

Banyak keuntungan yang didapatkan oleh organisasi dari penerapan QFD. Pertama, menurut Jeong dan Oh (1998), penerapan QFD pada industri yang memiliki sumber daya terbatas dapat memaksimalkan keluaran perusahaan yang dihasilkan. Kedua, QFD memiliki hubungan yang positif dan signifikan dengan kinerja organisasi (Politis, 2005). Ketiga, QFD membantu menurunkan biaya pembuatan produk baru, menaikan pangsa pasar dan keuntungan, serta memperpendek arus perencanaan (Bayraktaroglu dan Ozgen, 2008). Keempat, penerapan QFD dapat membantu organisasi dalam merencanakan sebuah rencana produk yang sesuai dengan keinginan pelanggan, meningkatkan kerjasama timkerja, meningkatkan kepuasan pelanggan, menyediakan karyawan sebuah dokementasi sebuah rencana produk, dan meningkatkan efektivitas komunikasi (Mehrjerdi, 2010). Kelima, QFD muncul sebagai alternative teknik kualitas terbaik dalam perencanaan pengembangan produk dan proses kerja untuk alokasi finansial yang terbatas (Kumar, Antony, dan Dhakar, 2006).

\section{Kinerja Organisasi}

Kinerja organisasi atau organizational performance secara sederhana didefinisikan sebagai totalitas hasil kerja yang dicapai suatu organisasi. Penelitian Wijayanti dan Cahyadi (2018) melihat evaluasi kinerja bukan dari metriks pengukurannya (finansial dan non-finansial) namun lebih pada proses evaluasi kinerja itu dilakukan dalam organisasi.

Menurut Dess and Robinson (1984), tingkat kinerja organisasi menentukan bagaimana kondisi sebuah perusahaan dibandingkan dengan pesaingnya. Pada konteks IKM, pengukuran kinerja organisasi umumnya menggunakan indikator pengukuran kinerja non-finansial. Hal tersebut disebabkan oleh keterbatasan kemampuan dari sumber daya manusia pada IKM untuk melakukan pengukuran kerja finansial dan melakukan pengumpulan data yang diperlukan dalam pengukuran finansial (Sidik, 2012). Dimensi kinerja organisasi yang digunakan untuk mengukur kinerja organisasi pada IKM di Indonesia meliputi:

a. tingkat perputaran dan pertumbuhan karyawan, kepuasan pelanggan, pertumbuhan penjualan, dan inovasi (Sidik, 2012),

b. praktik manajemen kualitas dan kinerja operasional (Ulfah dan Susilo, 2013),

c. aspek kewirausahaan dan kompetensi SDM (Anggadwita dan Qaanita, 2014),

d. balance scorecard dan modal insani (Erwina, dkk., 2015),

\section{KERANGKA PEMIKIRAN DAN HIPOTESIS PENELITIAN}

Kerangka pemikiran yang dibangun dan diuji hubungannya dalam penelitian ini secara lengkap dapat dilihat pada Gambar 1. berikut ini:

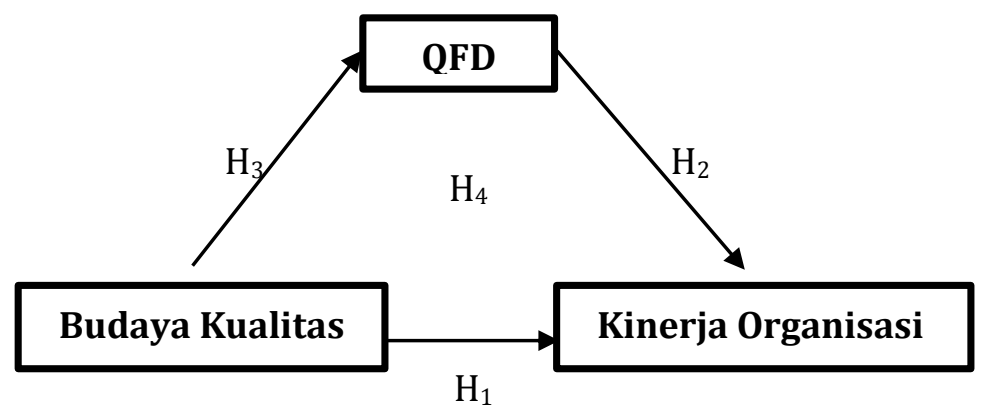


Pengaruh Budaya Kualitas Terhadap Kinerja Organisasi Dengan Quality Function Deployment sebagai Mediator Pada Ikm Sektor Logam Di Jawa Tengah

Gambar 1. Kerangka Pemikiran dan Hipotesis

\section{Hipotesis Penelitian}

Berdasarkan latar belakang dan permasalahan yang dikaji maka hipotesis penelitian ini meliputi: $\mathrm{H}_{1}$ : Budaya kualitas berpengaruh positif terhadap kinerja organisasi pada IKM sektor logam di Jawa Tengah.

$\mathrm{H}_{2}$ : QFD berpengaruh positif terhadap kinerja organisasi pada IKM sektor logam di Jawa Tengah. $\mathrm{H}_{3}$ : Budaya kualitas berpengaruh positif terhadap QFD pada IKM sektor logam di Jawa Tengah. $\mathrm{H}_{4}$ : QFD memediasi pengaruh positif budaya kualitas terhadap kinerja organisasi pada IKM sektor logam di Jawa Tengah.

\section{METODE PENELITIAN}

Penelitian ini bersifat exploratori kuantitatif yang dilaksanakan pada 93 unit IKM sektor logam di Jawa Tengah berdasarkan perhitungan rumus Slovin. Metode pengumpulan data yang digunakan dalam penelitian ini adalah kuisioner dengan instrument penelitian yang berupa skala likert. Pertanyaan kuisioner diberikan pada pemilik IKM dengan cara dengan datang langsung ke IKM maupun dikirim melalui media elektronik whatsapp dalam bentuk google form atau google formulir. Sebelum kuesioner dibagikan, butir pertanyaan kuesioner diuji dengan tes pilot. Selanjutnya, dilakukan uji asumsi klasik yang meliputi uji normalitas, linearitas, dan heteroskedastisitas untuk mengetahui apakah data berdistribusi normal dan linier atau tidak dan apakah kesimpulan dari analisis jalur bias atau tidak. Kemudian untuk untuk mengukur sah atau validnya suatu kuesioner dilakukan uji validitas dan untuk menguji tingkat ketepatan, ketelitian atau keakuratan kuesioner dilakukan uji reliabilitas. Analisis data mempunyai tujuan untuk menyampaikan dan membatasi penemuan penemuan hingga menjadi data yang teratur (Munidewi dan Pradipa, 2019). Terakhir, metode analisis data yang digunakan dalam penelitian ini adalah analisis regresi linier sederhana, analisis regresi untuk menguji variabel mediasi, dan sobel tes.

\section{HASIL DAN PEMBAHASAN}

\section{Hasil Uji Validitas}

Dalam penelitian ini memuat 30 indikator pernyataan. Berdasarkan hasil perhitungan uji validitas menunjukkan bahwa nilai $r$ hitung untuk masing - masing indikator lebih besar daripada nilai $\mathrm{r}$ tabel yaitu sebesar $0,1716(\mathrm{df}=91)$. Nilai $\mathrm{df}$ didapat dari perhitungan $\mathrm{df}=\mathrm{N}-2$, sehingga $93-2=91$. Dengan demikian dapat diinterpretasikan bahwa setiap item indikator instrumen untuk mengukur besarnya kinerja organisasi tersebut adalah valid.

\section{Hasil Uji Reliabilitas}

Hasil dari uji tersebut kemudian dibandingkan dengan pertanyaan lainnya atau dengan kata lain mengukur korelasi antar jawaban pertanyaan. Hasil perhitungan uji reliabilitas untuk masing - masing item variabel dikatakan reliable karena menunjukkan nilai Cronbach Alpha $(\alpha)$ untuk masing - masing variabel adalah lebih besar dari 0,60 sebagaimana pendapat Ghozali (2009:162). 


\section{Hasil Uji Asumsi Klasik}

\section{Uji Normalitas}

Dalam penelitian ini, pengujian normalitas menggunakan perbandingan rasio skewness dan rasio kurtosis. Data disebut berdistribusi normal jika rasio skewness dan kurtosis berada diantara -2 hingga +2 . Dari hasil pengujian diketahui bahwa rasio skewness $=-0,156 / 0,250$ sedangkan rasio kurtosis $=0,121 / 0,495$. Sehingga data disebut berdistribusi normal.

\section{Uji Linieritas}

Dalam penelitian ini, pengujian linearitas dilakukan sebanyak tiga kali. Pengujian tersebut meliputi pengujian hubungan variabel budaya kualitas dengan kinerja organisasi, pengujian hubungan variabel QFD dengan kinerja organisasi, dan pengujian hubungan variabel budaya kualitas dengan QFD. Dari hasil pengujian diketahui bahwa model penelitian bersifat linier dilihat dari nilai deviasi linieritas secara berturut - turut yaitu 0,$624 ; 0,787 ; 0,509$ yang lebih besar dari nilai 0,05 .

\section{Uji Heteroskedastisitas}

Hasil uji heteroskedastisitas menggunakan uji gletjser menunjukkan bahwa tidak terjadi masalah heteroskedastisitas pada model regresi. Hal itu dapat diketahui dari nilai sig. variabel budaya kualitas (X1) dan QFD (X2) adalah 1,000 yang lebih dari 0,05.

\section{Analisis Regresi Linier Sederhana}

Pengujian hipotesis $\mathrm{H}_{1}, \mathrm{H}_{2}$, dan $\mathrm{H}_{3}$ adalah bentuk pengujian langsung atau direct effect. Dalam penelitian ini, pengujian hipotesis tersebut dilakukan dengan menggunakan analisis regresi linier sederhana. Berdasarkan pengolahan data dengan bantuan program IBM SPSS Statististics 20 diperoleh hasil analisis sebagai berikut:

Tabel 4. Hasil Pengujian Regresi Linier Sederhana

\begin{tabular}{ccccccccc}
\hline Model Empiris & $\mathbf{R}$ & $\mathbf{R}^{2}$ & $\mathbf{F}$ & $\mathbf{F}_{\text {tabel }}$ & $\mathbf{T}$ & $\mathbf{t}_{\text {tabel }}$ & B koef. & $\boldsymbol{p}$ \\
\hline $\mathrm{BK} \rightarrow \mathrm{KO}\left(\mathrm{H}_{1}\right)$ & 0,395 & 0,156 & 16,797 & 3,95 & 4,098 & 1,662 & 0,419 & 0,000 \\
& & & & & & & & \\
$\mathrm{QFD} \rightarrow \mathrm{KO}\left(\mathrm{H}_{2}\right)$ & 0,284 & 0,081 & 7,985 & 3,95 & 2,826 & 1,662 & 0,196 & 0,006 \\
& & & & & & & & \\
$\mathrm{BK} \rightarrow \mathrm{QFD}\left(\mathrm{H}_{3}\right)$ & 0,662 & 0,438 & 70,995 & 3,95 & 8,426 & 1,662 & 1,020 & 0,000
\end{tabular}

Sumber: Hasil Olah Data (2019)

BK = Budaya Kualitas, QFD = Quality Function Deployment, KO = Kinerja Organisasi

Sedangkan untuk pengujian hipotesis $\mathrm{H}_{4}$ dilakukan dengan analisis regresi linier dengan pemediasi. Adapun hasil pengujian hipotesis dapat dilihat pada tabel 5. berikut ini:

Tabel 5. Hasil Pengujian Regresi Linier Dengan Pemediasi

\begin{tabular}{|c|c|c|c|c|c|c|}
\hline \multirow{2}{*}{\multicolumn{2}{|c|}{ Empiris }} & \multicolumn{4}{|c|}{ Regresi } & \multirow[b]{2}{*}{ Ket. } \\
\hline & & Koef. $\boldsymbol{\beta}$ & $\begin{array}{l}\text { Std. } \\
\text { eror }\end{array}$ & P Value & Sig. & \\
\hline A. & $\mathrm{BK} \rightarrow \mathrm{QFD}$ & 1,020 & 0,121 & 0,000 & $S$ & $a$ \\
\hline B. & $\mathrm{BK} \rightarrow \mathrm{KO}$ & 0,419 & 0,102 & 0,000 & S & C \\
\hline \multirow[t]{3}{*}{ C. } & $\mathrm{BK} \rightarrow \mathrm{QFD} \rightarrow \mathrm{KO}$ & & & & & \\
\hline & BK & 0,391 & 0,137 & 0,005 & S & $c^{1}$ \\
\hline & QFD & 0,028 & 0,089 & 0,755 & TS & $b$ \\
\hline
\end{tabular}

Sumber: Hasil Olah Data (2019) 
Berdasarkan hasil analisis pada model summary dan coefficients maka model hasil analisis adalah sebagai berikut:

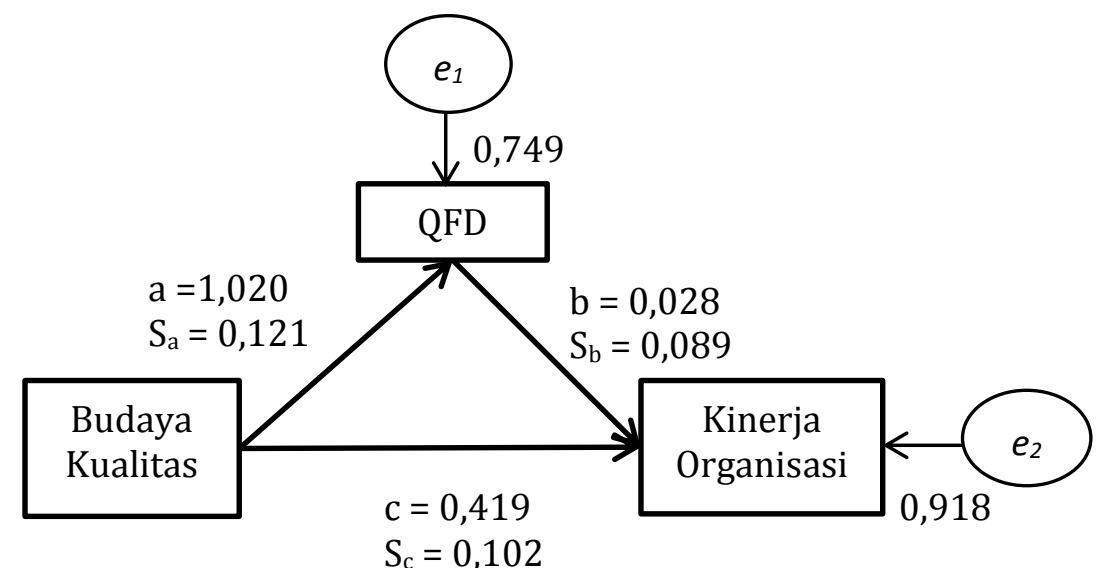

Gambar 2. Hasil Analisis Model Regresi $\mathrm{H}_{4}$

Uji sobel dilakukan untuk mengetahui kekuatan atau signifikansi pengaruh tidak langsung variabel budaya kualitas $(\mathrm{X})$ terhadap kinerja organisasi $(\mathrm{Y})$ melalui variabel QFD (M). Pengujian sobel dilakukan dengan langkah - langkah seperti berikut ini:

1. Menghitung standar error koefisien pengaruh tidak langsung dengan menggunakan rumus $S_{a b}=\sqrt{b^{2} S_{a}^{2}+a^{2} S_{b}^{2}+S_{a}^{2} \cdot S_{b}^{2}}$

2. Menghitung nilai t statistik pengaruh mediasi menggunakan rumus $t=\frac{a b}{S_{a b}}$

Selain itu, pengujian secara online juga perlu dilakukan untuk mendapatkan nilai $P_{v a l u e}$. Pengujian secara online dapat dilakukan di http://quantpsy.org/sobel/sobel.htm. Hasil pengujian sobel tes dapat dilihat pada gambar 3. berikut ini:

\begin{tabular}{|c|c|c|c|c|}
\hline Input: & & Test statistic: & Std. Error: & $p$-value: \\
\hline a 1.020 & Sobel test: & 0.31438787 & 0.0908432 & 0.75322647 \\
\hline$b 0.028$ & Aroian test: & 0.31220185 & 0.09147928 & 0.75488713 \\
\hline$s_{a} 0.121$ & Goodman test: & 0.31662046 & 0.09020264 & 0.75153161 \\
\hline So 0.089 & Reset all & & Calculate & \\
\hline
\end{tabular}

Gambar 3. Hasil Perhitungan Sobel Test $\mathrm{H}_{4}$

Berdasarkan hasil uji hipotesis dapat diketahui bahwa terdapat 3 hipotesis yang diajukan yang diterima, dan 1 hipotesis yang ditolak. Adapun hasil pengujian hipotesis penelitian secara lebih jelas dapat diuraikan sebagai berikut:

1. Model regresi untuk meneliti hipotesis adanya pengaruh positif budaya kualitas terhadap kinerja organisasi $\left(\mathrm{H}_{1}\right)$ dapat dikatakan fit dilihat dari nilai $\mathrm{F}$ hitung $=16,797$ lebih besar daripada nilai $\mathrm{F}_{\text {tabel }}=3,95(\mathrm{df}=91)$ dan niilai sig. $=0,000$ lebih kecil dari $\alpha=0,05$. Sedangkan besarnya pengaruh budaya kualitas terhadap kinerja organisasi adalah sebesar $\mathrm{R}^{2}=0,156$ atau 15,6 \%. Disisi lain, berdasarkan nilai $t_{\text {hitung }}=4,098$ dengan nilai sig. $=0,000$ lebih besar 
dari nilai $\mathrm{t}_{\text {tabel }}=1,662$ dan nilai $p_{\text {value }}=0,000$ lebih kecil dari $\alpha=0,05$ menunjukan bahwa pengaruh budaya kualitas terhadap kinerja organisasi adalah positif signifikan dan hipotesis pertama $\left(\mathrm{H}_{1}\right)$ dapat diterima.

2. Model regresi untuk meneliti hipotesis adanya pengaruh positif QFD terhadap kinerja organisasi $\left(\mathrm{H}_{2}\right)$ dapat dikatakan fit dilihat dari nilai $\mathrm{F}_{\text {hitung }}=7,985$ lebih besar dari nilai $\mathrm{F}_{\text {tabel }}=$ $3,95(\mathrm{df}=91)$ dan nilai sig. $=0,006$ lebih kecil dari $\alpha=0,05$. Sedangkan besarnya pengaruh QFD terhadap kinerja organisasi adalah sebesar sebesar $\mathrm{R}^{2}=0,081$ atau 8,1\%. Disisi lain, berdasarkan nilai $t_{\text {hitung }}=2,826$ dengan nilai sig. $=0,006$ lebih besar dari nilai $t_{\text {tabel }}=1,662$ dan nilai $p_{\text {value }}=0,006$ lebih kecil dari $\alpha=0,05$ menunjukan bahwa pengaruh QFD terhadap kinerja organisasi adalah positif signifikan dan hipotesis kedua $\left(\mathrm{H}_{2}\right)$ dapat diterima.

3. Model regresi untuk meneliti hipotesis adanya pengaruh positif budaya kualitas terhadap QFD $\left(\mathrm{H}_{3}\right)$ dapat dikatakan fit dilihat dari nilai $\mathrm{F}_{\text {hitung }}=70,995$ lebih besar dari nilai $\mathrm{F}_{\text {tabel }}=3,95 \mathrm{df}$ $=91$ ) dan nilai sig. $=0,000$ lebih kecil dari $\alpha=0,05$. Sedangkan besarnya pengaruh budaya kualitas terhadap QFD adalah sebesar sebesar $\mathrm{R}^{2}=0,438$ atau 43,8 \%. Disisi lain, berdasarkan nilai $\mathrm{t}_{\text {hitung }}=8,426$ dengan nilai sig. $=0,000$ lebih besar dari nilai $\mathrm{t}_{\text {tabel }}=1,662$ dan nilai $p_{\text {value }}$ $=0,006$ lebih kecil dari $\alpha=0,05$ menunjukan bahwa pengaruh budaya kualitas terhadap QFD adalah positif signifikan dan hipotesis ketiga $\left(\mathrm{H}_{3}\right)$ dapat diterima.

4. Dari hasil perhitungan, nilai t_hitung $=0,31438787$ lebih kecil dibandingkan nilai t_tabel $=$ 1,66196 ( $\alpha=0,05$ dan $\mathrm{df}=90$ dengan $\mathrm{k}=3)$. Sedangkan nilai $\mathrm{p}$ 『(P】_value) dari hasil perhitungan Sobel Test pada Gambar 5 adalah sebesar 0,75322647 lebih besar dari 0,05 $\alpha=$ $5 \%$ ), artinya variabel QFD tidak memiliki fungsi mediasi terkait pengaruh positif budaya kualitas terhadap kinerja organisasi. Hal ini menunjukan ditolaknya hipotesis keempat yang menyatakan bahwa QFD memediasi positif pengaruh budaya kualitas terhadap kinerja organisasi atau dapat disimpulkan bahwa $\mathrm{H} 4$ ditolak.

\section{PEMBAHASAN}

\section{Pengaruh Positif Budaya Kualitas terhadap Kinerja Organisasi}

Budaya kualitas signifikan memberikan pengaruh positif terhadap kinerja organisasi. Hal tersebut berarti pengembangan budaya kualitas mempunyai peran positif dalam mendukung peningkatan kerja organisasi. Hasil penelitian ini secara teoritis mendukung hasil penelitian yang ditemukan oleh Dubey, dkk. (2015) bahwa budaya kualitas memberikan dampak positif terhadap peningkatan kinerja organisasi pada industri manufaktur berskala kecil dan menengah di India.

\section{Pengaruh Positif QFD terhadap Kinerja Organisasi}

QFD signifikan memberikan pengaruh positif terhadap kinerja organisasi. Hal tersebut berarti QFD mempunyai peran positif dalam mendukung peningkatan kinerja organisasi. Hasil penelitian ini secara teoritis selaras dengan hasil penelitian sebelumnya. Pertama, penelitian yang dilakukan Politis (2005) pada sembilan perusahan di Uni Emirate Arab menghasilkan bahwa QFD berhubungan positif dan signifikan dengan kinerja organisasi. Kedua, pengaruh positif penerapan QFD terhadap kinerja organisasi juga ditunjukkan pada hasil penelitian Gonzales, dkk. (2004) pada studi kasus di sektor perbankan di Spanyol yang menemukan bahwa QFD menjadi alat bagi manajer projek untuk peningkatan kinerja melalui kualitas.

\section{Pengaruh Positif Budaya Kualitas Terhadap QFD}

Budaya kualitas signifikan memberikan pengaruh positif terhadap QFD. Hal tersebut berarti pengembangan budaya kualitas sebagai variabel yang mempengaruhi atau antecedent mempunyai peran positif dalam mendukung kesuksesan penerapan QFD. Hasil penelitian ini 
Pengaruh Budaya Kualitas Terhadap Kinerja Organisasi Dengan Quality Function Deployment sebagai Mediator Pada Ikm Sektor Logam Di Jawa Tengah

selaras dengan hasil penelitian Roldan, dkk. (2012) pada 113 perusahan agensi yang menemukan bahwa budaya kualitas berpengaruh positif terhadap kesuksesan pelaksanaan TQM dan penelitian Gambi, dkk., (2015) yang menyebutkan bahwa peranan budaya organisasi (budaya kualitas) dalam penerapan teknik manajemen kualitas (QFD) adalah sebagai variabel antecedent.

\section{Peranan QFD dalam Memediasi Pengaruh Positif Budaya Kualitas Terhadap Kinerja Organisasi}

Pengaruh QFD sebagai Mediator tidak memediasi pengaruh positif budaya kualitas terhadap kinerja organisasi. Hal tersebut berarti peranan QFD sebagai pemediasi masih lemah dalam mendukung peningkatan kinerja organisasi melalui pengembangan budaya kualitas. Dengan kata lain, budaya kualitas berpengaruh secara langsung terhadap kinerja organisasi tanpa melalui QFD sebagai mediator.

Salah satu alasan mengapa QFD tidak memediasi positif pengaruh budaya kualitas terhadap kinerja organisasi adalah lingkungan kerja IKM yang kurang mendukung kesuksesan penerapan QFD. Berdasarkan teori dan praktek penerapan QFD yang dilakukan oleh Politis (2005) dalam mengkaji hubungan positif dan signifikan antara QFD dan kinerja organisasi, terdapat tujuh instrumen yang mengkonstruksi atau memfasilitasi dimensi lingkungan kerja yang mendukung kesuksesan penerapan QFD. Ketujuh instrumen tersebut meliputi perencanaan strategis QFD, fokus pada pelanggan dan pasar, informasi dan analisis QFD, fokus sumber daya manusia pada QFD, Pelatihan QFD untuk atasan, komitmen manajemen puncak pada QFD, serta kolaborasi pekerja dan atasan pada upaya QFD. Ketujuh instrumen tersebut dikembangkan pada organisasi yang mendapatkan penghargaan kualitas dari Departemen Pengembangan Ekonomi di Dubai dan telah memulai berbagai program manajemen kualitas seperti ISO 9000, TQM, dan kaizen. Dengan kata lain, penerapan QFD dapat menjadi pemediasi yang baik jika organisasi mampu mengembangkan instrumen - instrumen yang memfasilitasi dimensi lingkungan kerja yang mendukung kesuksesan pelaksanaan QFD.

\section{KESIMPULAN, IMPLIKASI, DAN SARAN \\ Kesimpulan}

Penelitian ini bertujuan untuk menguji pengaruh budaya kualitas terhadap kinerja organisasi dengan QFD sebagai variabel pemediasi. Berdasarkan analisis dan pembahasan yang telah dilakukan sebelumnya dapat ditarik kesimpulan sebagai berikut ini:

1. Budaya kualitas signifikan memberikan pengaruh positif terhadap kinerja organisasi. Hal tersebut berarti pengembangan budaya kualitas mempunyai peran positif dalam mendukung peningkatan kerja organisasi.

2. QFD signifikan memberikan pengaruh positif terhadap kinerja organisasi. Hal tersebut berarti QFD mempunyai peran positif dalam mendukung peningkatan kinerja organisasi.

3. Budaya kualitas signifikan memberikan pengaruh positif terhadap QFD. Hal tersebut berarti pengembangan budaya kualitas mempunyai peran positif dalam mendukung kesuksesan penerapan QFD.

4. QFD tidak memediasi pengaruh positif budaya kualitas terhadap kinerja organisasi. Hal tersebut berarti peranan QFD sebagai pemediasi masih lemah dalam mendukung peningkatan kinerja organisasi melalui pengembangan budaya kualitas. 


\section{Implikasi}

Berdasarkan hasil penelitian ini, implikasi yang dibuat meliputi:

1. Budaya kualitas dan QFD memberikan pengaruh positif signifikan terhadap kinerja organisasi. Hasil penelitian ini diharapkan dapat menjadi referensi bagi organisasi untuk mengembangkan budaya kualitas dan menerapkan QFD pada lingkungan kerja.

2. Budaya kualitas sebagai variabel yang mempengaruhi atau antecedent memberikan pengaruh positif signifikan terhadap kesuksesan QFD. Dari hasil penelitian diketahui bahwa pengaruh budaya kualitas terhadap QFD hampir mendekati 50\% yang artinya budaya kualitas memiliki andil yang cukup besar terhadap kesuksesan penerapan QFD. Hasil penelitian ini diharapkan dapat menjadi masukan bagi organisasi untuk lebih memperhatikan budaya organisasi yang berkembang pada lingkungan kerja sebelum menerapkan QFD. Salah satu budaya organisasi yang tepat untuk diterapkan adalah budaya kualitas.

3. QFD sebagai variabel mediator tidak memberikan efek pemediasi atau pengaruh tidak langsung pada pengaruh positif budaya kualitas terhadap kinerja organisasi. Hasil penelitian ini menunjukkan bahwa budaya kualitas yang dikembangkan pada lingkungan kerja memiliki pengaruh langsung dalam peningkatan kinerja organisasi. Hasil penelitian ini diharapkan menjadi masukan bagi organisasi terutama industri kecil dan menengah untuk dapat lebih mengupayakan hal - hal yang dapat dilakukan dan dikembangkan pada lingkungan kerja agar memberikan dukungan yang lebih besar terhadap pencapaian kinerja organisasi yang lebih baik.

\section{Saran}

1. Perlunya pengembangan model penelitian untuk menambah kepustakaan dalam bidang manajemen sumber daya manusia dan manajemen operasional.

2. Penelitian dalam konteks yang sama mengenai upaya peningkatan kinerja organisasi melalui pengelolaan kualitas dapat memberikan referensi kepada penelitian selanjutnya yang dilakukan di IKM.

3. Berdasarkan hasil penelitian ini dapat dijadikan sebagai bahan evaluasi oleh pemilik IKM dan stakeholder mengenai pentingnya pengembangan budaya kualitas

4. IKM sektor logam dapat menjadikan hasil penelitian ini sebagai landasan dalam membuat suatu kebijakan yang berkaitan dengan upaya peningkatan kinerja organisasi.

\section{DAFTAR PUSTAKA}

Adebanjo, D. and Kehoe, D. (1999). An investigation of quality culture development in UK industry. International Journal of Operations \& Production Management. 19(7): 633-49.

Akao, Y. (1990). Quality Function Deployment: Integrating Customer Requirements into Product Design. Cambridge: Productivity Press, MA.

Ali, Hairuddin Mohd dan Mohammed Borhandden Musah. (2012). Investigation of Malaysian Higher Education Quality Culture and Workforce Performance. Quality Assurance in Education. 20(3): 289-309.

Anggadwita, Grisna dan Qaanita Yuuha Mustafid. (2014). Identification of Factors Influencing the Performance of Small Medium Enterprise (SMEs). Social and Behavioral Sciences.415 423.

Barrett, Rowena dan Susan Mayson. (2007). Human Resource Management in Growing Small Firms. Journal of Small Business and Enterprise Development. 14(2): 307-320. 
Bashayreh, Anas M. (2014). Organizational Culture and Effect on Organizational Performance: Study on Jordanian Insurance Sector. International Journal of Knowledge and Systems Science. 5(2): 35-48.

Besterfield, D.H., Besterfield-Michna, C., Besterfield, G.H. and Besterfield-Sacre, M. (1999). Total Quality Management. Edisi kedua. Prentice-Hall: Englewood Cliffs, NJ.

Bayraktaroglu dan Ozgen. (2008). Integrating the Kano model, AHP and Planning Matrix QFD, Application in Library Services. Library Management. 29(4/5): 327-351.

Dess, G.G. and Robinson, R.B. Jr. (1984). Measuring Organizational Performance in the Absence of Objective Measures. Strategic Management Journal. 5: 265-73.

Dubey, Singh, dan Ali. (2015). The Mediating Effect of Human Resource on Successful Total Quality Management Implementation: An Empirical Study on SMEs in Manufacturing Sectors. Benchmarking: An International Journal. 22(7): 1463-1480.

Ehlers, U. D. (2009). Understanding quality culture. Quality Assurance in Education. 343-363.

Erwina, Anggraini, dan I Made. (2015). Perancangan Balance Scorecard untuk Mengembangkan Modal Insani dan Meningkatkan Kinerja. Jurnal Aplikasi Manajemen. 13(3): 446-456.

Ghozali, Imam. (2009). Aplikasi Analisis Multivariate Dengan Program SPSS. Edisi Keempat, Penerbit Universitas Diponegoro.

Goetsch dan David. (2000). Quality Management (Introduction to total quality management for production, processing, and service). Third edition. Prentice Hall International, Inc.

Gonzalez, dkk. (2004). Customer Satisfaction Using QFD: an E-banking Case. Managing Service Quality. 14(4): 317-330.

Heizer, Jay dan Barry Render. (2015). Manajemen Operasi, Manajemen Keberlangsungan dan Rantai Pasokan. Edisi 11. Jakarta: Penerbit Salemba Empat.1000 hal.

Indayati, Nurul, dkk. (2012). Pengaruh Keterlibatan Karyawan, Budaya Organisasi, dan Gaya Kepemimpinan terhadap Komitmen Organisasional dalam Meningkatkan Kinerja Karyawan (Studi pada Universitas Brawijaya). Jurnal Aplikasi Manajemen. 10(2): 344-356.

Jeong, Miyoung dan Haemoon, Oh. (1998). Quality Function Deployment: An Extended Framework for Service Quality and Customer Satisfaction In The hospitality Industry. Hospitality Management. 17: 375-390.

Johnson, J.J. (2000). Differences in Supervisor and Non-Supervisor Perceptions of Quality Culture and Organizational Climate. Public Personnel Management. Vol. 29 No. 1, ProQuest Education Journals.199.

Kanji, Gopal dan William Wallace. (2000). Business Excellence through Customer Satisfaction. Total Quality Management. 11(7): 979-998.

Kumar, Antony, dan Dhakar. (2006). Integrating Quality Function Deployment, and Benchmarking to Achieve Greater Profitability. Benchmarking: An International Journal. 13(3): 290-310.

Mehrjerdi, Yahia Zare. (2010). Quality Function Deployment and Its Extensions. International Journal of Quality \& Reliability Management. 27(6): 616-640.

Mosadeghrad, Ali Mohammad. (2015). Developing and Validating a Total Quality Management Model for Healthcare Organisation. The TQM Journal. 27(5): 544-564.

Munizu, dkk. (2011). Pengaruh Praktik Total Quality Management (TQM) terhadap Budaya Kualitas, Daya Saing dan Kinerja Perusahaan (Studi pada Industri Manufaktur di Kota Makassar). Jurnal Aplikasi Manajemen. 10(3): 510-519. 
Murphy, dkk. (2013). Firm Culture and Performance: Intensity's Effects and Limits. Management Decision. 51(3): 661-679.

Munidewi, I.A.B., dan Pradipa, N.A. (2019). Faktor-Faktor yang Berpengaruh Terhadap Penerimaan Opini Going Concern Pada Perusahaan Manufaktur yang Mengalami Financial Distress. Jurnal Soedirman Accounting Review. 03 (01): 101-126.

Nazarian, Alireza, dkk. (2017). Influence of National Culture and Balanced Organizational Culture on the Hotel Industry's Performance. International Journal of Hospitality Management. 63: $22-32$.

Ndubisi, Nelson Oli, dan James Agarwal. (2014). Quality Performance of SMEs in a Developing Economy: Direct and Indirect Effects of Service Innovation and Entrepreneurial Orientation. Journal of Business \& Industrial Marketing. 29(6): 454-468.

Noe, dkk. (2014). Manajemen Sumber Daya Manusia Mencapai Keunggulan Bersaing. Edisi 6. Jakarta: Salemba Empat. 625 hal.

(2014). Manajemen Sumber Daya Manusia Mencapai Keunggulan Bersaing. Edisi 6. Jakarta: Salemba Empat. 390 hal.

Ogbonna, E., and Harris, L.C. (2000). "Leadership Style, Organizational Culture and Performance: Empirical Evidence From UK Companies," International Journal of Human Resource Management. 11(4): 766-788.

Politis, John, D. (2005). QFD, Organisational Creativity and Prodductivity. International Journal of Quality dan Reliability Management. 22(1): 59-71.

Roldan, dkk. (2012). The Influence of Organisational Culture on the Total Quality Management Programme Performance. Investigaciones Europeas de Direccion y Economia de la Empresa. 5: 183-189.

Sidik, Ignas G. (2012). Conceptual Framework of Factors Affecting SME Development: Mediating Factors on the Relationship of Entrepreneur Traits and SME Performance. Procedia Economics and Finance. 7: 373 - 383.

Sommerville, J. dan Sulaiman, N. F. (1997). The culture for quality within the UK construction industry: temporal relatedness and dominance. Total Quality Management. 8(2): 279 285.

Tseng, Shu-Mei. (2009). The Correlation between Organizational Culture and Knowledge Conversion on Corporate Performance. Journal of Knowledge Management. 269-284.

Ulfah, Fitriana, dan Susilo Toto Rahardjo. (2013). Analisis Pengaruh Implementasi Manajemen Kualitas Terhadap Kinerja Organisasi Pada Usaha Kecil Menengah Di Kota Salatiga. Jurnal Studi Manajemen dan Organisasi. 10(1): 22-37.

Waal, Andre de dan Suhail Sultan. (2012). Applicability of the High Performance Organization Framework in the Middle East: The case of Palestine Polytechnic University. Education, Business and Society: Contemporary Middle Eastern Issues. 5(3): 213-223.

Wijayanti, Dian dan Cahyadi, Sendy. (2018). Pengaruh Proses Evaluasi Kinerja Terhadap Persepsi Procedural Fairness: Studi Di Perguruan Tinggi. Jurnal Soedirman Accounting Review. Vol 03 (01): 56-72.

Wilson, Frankie. (2015). The Quality Maturity Model: Your Roadmap to a Culture of Quality. Library Management. 36(3): 258-267.

$\mathrm{Wu}$, dkk. (2011). Customization of quality practices: the impact of quality culture. International Journal of Quality \& Reliability Management. 28 